\title{
フライアッシュコンクリートの 簡易品質評価手法に関する研究
}

\author{
楠 貞則 1 ・添田 政司 $2 \cdot$ 大和 竹史 3 \\ 1正会員 福岡大学助教 工学部社会デザイン工学科（†814-0180 福岡市城南区七隈8-19-1） \\ E-mail: kusunoki@fukuoka-u.ac.jp \\ 2正会員 福岡大学大学院教授 資源循環工学専攻（干814-0180 福岡市城南区七隈8-19-1） \\ 3フェロー 福岡大学教授 工学部社会デザイン工学科（†814-0180 福岡市城南区七隈8-19-1）
}

\begin{abstract}
フライアッシュをコンクリート混和材として利用する場合，JISで品質が分類されているものの，使用す るフライアッシュの品質によってコンクリートの品質変動が大きいことが懸念され，フライアッシュの有 効利用拡大の妨げとなっている。また，近年，フライアッシュを細骨材の一部に代替した利用も進められ ているが，このフライアッシュコンクリートの品質管理手法について十分とは言えない. 本研究はフライ アッシュの品質特性を簡易に評価する手法とフライアッシュの品質がフレッシュコンクリートの性状に与 える影響について実験的検討を行った。この結果，フライアッシュの品質の中で特に重要な未燃カーボン 量の簡易測定手法を提案するとともに，簡易なモルタル試験によるフライアッシュコンクリートの性状評 価手法の提案も行った.
\end{abstract}

Key Words : fly ash, mineral admixture, replacement as fine aggregate, unburnt carbon content, quality control method, percent flow

\section{1. はじめに}

石炭火力発電所運転に伴い排出される石炭灰の発生量 は, 電力需要の拡大と伴に年々増加し, 定常的に年間 1,000万トンを超えている ${ }^{1)}$. この石炭灰の大部分を占め るフライアッシュは, コンクリート混和材としてJIS A 6201で規格化され, 単位水量の低減, 水和熱の抑制, ASR の抑制等の品質改善が期待されるものの, そのコンク リート混和材としての利用は $1 \%$ に満たないのが現状で ある ${ }^{1)}$ 。この有効利用の妨げとなる要因の一つに，フラ イアッシュをコンクリート混和材として利用する場合, JISで品質が分類（I種～IV種）されているものの, 使用 するフライアッシュの品質によってコンクリートの品質 変動が生じることが上げられ，特にフライアッシュ中の 未燃カーボンの変動がフライアッシュを混入したコンク リートの品質に与える影響が大きい2,3).このフライアッ シュの品質管理については, これまで多くの研究実績が あり, JISの品質規格の測定を含め確立された面もある しかし，フライアッシュの品質変化がコンクリートのフ レッシュ性状等に与える影響を十分把握しているとは言 えず, また, フライアッシュの品質管理の測定項目によっ ては熟練や煩雑な工程を要し，時間やコストがかかるた め必ずしも適切と言えないのが現状である゙。 このため,
$\mathrm{JIS}$ 品質保証のみならず, フライアッシュの品質変動を 精度よく, しかも容易に把握できれば, 即応したコンク リートの配合修正が可能となり，フライアッシュのコン クリート混和材としての利便性の向上が期待できるもの と考えられる.

ここで，フライアッシュの規格分類のうち，一般に流 通しているものはII種（以下，JIS II種と示寸）がほとん どである. JIS II種の品質変動について, 江藤らは7), 同 一発電所から排出されるJIS II種のフライアッシュを, 約 18ヶ月間にわたり定期的に採取し，この品質変動がコン クリートに及ぼす影響について検討している.この中で, JIS II種であってもコンクリートの流動性や空気量が未 燃カーボン量の変動に起因している可能性を示唆してい る、筆者らの既報伒おいても，フライアッシュが同一 規格であっても使用するフライアッシュの品質によって 流動性に違いがあることを定量的に示している.このフ ライアッシュの品質のばらつきは，石炭火力発電所，燃 焼工程および石炭の原産地などの違いによるものと予想 され，同一規格内でも品質に幅があることが分かる．ま た, 最近の海砂採取規制や天然骨材枯渴などの問題を背 景に，フライアッシュを細骨材補充混和材として細骨材 の一部に代替したフライアッシュコンクリートの利用も 進められている.この指針として，土木学会四国支部の 
表-1 フライアッシュの物理化学的性質

\begin{tabular}{|l|c|c|c|c|c|c|c|c|c|c|}
\hline 試料名 & $\begin{array}{c}\text { 湿分 } \\
(\%)\end{array}$ & $\begin{array}{c}\text { 強熱 } \\
\text { 減量 } \\
(\%)\end{array}$ & $\begin{array}{c}\text { 二酸化 } \\
\text { けい素 } \\
(\%)\end{array}$ & $\begin{array}{c}\text { 比表面積 } \\
\left(\mathrm{cm}^{2} / \mathrm{g}\right)\end{array}$ & $\begin{array}{c}45 \mu \mathrm{m} \\
\text { 残分 } \\
(\%)\end{array}$ & $\begin{array}{c}\text { 密度 } \\
\left(\mathrm{g} / \mathrm{cm}^{3}\right)\end{array}$ & $\begin{array}{c}\text { 炭素量 } \\
(\%)\end{array}$ & $\begin{array}{c}\text { M.B. } \\
\text { 吸着量 } \\
(\mathrm{mg} / \mathrm{g})\end{array}$ & $\begin{array}{c}\text { 密かさ } \\
\text { 比重 }\end{array}$ & $\begin{array}{c}\text { 平均径 } \\
(\mu \mathrm{m})\end{array}$ \\
\hline F1 & 0.10 & 0.8 & 67.0 & 3880 & 3 & 2.29 & 1.11 & 0.45 & 1.34 & 12.48 \\
\hline F2 & 0.04 & 1.4 & 55.6 & 4200 & 3 & 2.36 & 0.89 & 0.22 & 1.46 & 13.25 \\
\hline F3 & 0.08 & 1.7 & 53.2 & 3870 & 9.3 & 2.29 & 1.44 & - & 1.35 & 19.90 \\
\hline F4 & 0.04 & 1.3 & 57.4 & 3560 & 8.7 & 2.32 & 2.54 & - & 1.24 & 16.12 \\
\hline F5(1) & 0.13 & 2.6 & 61.1 & 4180 & 1 & 2.28 & 2.24 & 0.32 & 1.19 & 15.74 \\
\hline F5(2) & 0.06 & 1.7 & 62.4 & 4000 & 1 & 2.27 & 2.05 & - & 1.19 & 17.38 \\
\hline F5(3) & 0.10 & 0.4 & 57.3 & 3150 & 24 & 2.30 & 0.44 & 0.07 & 1.45 & 25.98 \\
\hline F5(4) & 0.20 & 2 & 57.3 & 3170 & 21 & 2.22 & 2.07 & 0.24 & 1.33 & 28.33 \\
\hline JIS II種 & $\leqq 1.0$ & $\leqq 5.0$ & $\geqq 45.0$ & $\geqq 2500$ & $\leqq 40$ & $\geqq 1.95$ & - & - & - & - \\
\hline
\end{tabular}

「フライアッシュを細骨材補充混和材として用いたコン クリートの施工指針 (案)」がある9)。この中で，細骨材 補充混和材として使用するフライアッシュは, JIS規格分 類でII種とIV種が対象となっている. このようにフライ アッシュの有効利用技術の開発が進むものの, フライ アッシュの品質変動がコンクリートの特性に与える影響 は十分に検討されているとは言えない. 以上のことから， 今後, フライアッシュの有効利用促進を図るには, JISの 同一規格内であっても品質変動を精度よく把握し，フラ イアッシュの品質がコンクリートのスランプ, 空気量の フレッシュ性状に与える影響に対処できる品質管理手法 を確立することが必要と考えられる。

本研究は, フライアッシュの物性評価として未燃カー ボン量を正確且つ簡易に定量可能な手法の提案を行うと ともに，モルタル試験によるフライアッシュの品質評価 およびそれを用いたフライアッシュコンクリートの性状 評価手法の提案について実験的に検討した結果を報告す るものである.

\section{2. 実験概要}

\section{（1）使用材料}

実験に使用したフライアッシュは, 日本国内の4電力会 社 5 石炭火力発電所より通常採取されるJIS II種である (F1 Ｆ5). F5 は，同一発電所において4回採取日を変えて採 取した（F5(1)〜F5(4)）。このフライアッシュの特徵は, JIS II種の中でも強熱減量が3\%以下で品質が安定したも のである. フライアッシュの物理化学的性質を表ー1に示 す.フライアッシュの物理化学的性質は, フライアッシュ の品質規格に関するJIS規格（JIS A 6201）に加えて,メチ レンブルー吸着量 (CAJS I-61), 密かさ比重), およびレー ザー回折式粒度測定装置により平均径を測定した. なお, 全炭素量は2. (2)で詳細を記述する. セメントは, 普通ポ ルトランドセメント (密度 $3.16 \mathrm{~g} / \mathrm{cm}^{3}$, 比表面積 $3,280 \mathrm{~g} / \mathrm{cm}^{2}$ )
を使用した。細骨材は，モルタル試験にはセメント物理 試験用標準砂を, コンクリート試験には海砂（密度 $2.58 \mathrm{~g} / \mathrm{cm}^{3}$, 吸水率 $0.96 \%$ ）を使用した。粗骨材は, 砕石 2005 (密度 $2.75 \mathrm{~g} / \mathrm{cm}^{3}$, 吸水率 $1.11 \%$ ）を使用した. また, 混和剤はAE減水剤を用い, 空気量は空気連行剤 (AE鼡) を用いて調整した。 なお，フライアッシュコンクリート にはフライアッシュ用のAE剤（高アルキルカルボン酸 系）を使用した。

\section{（2）未燃カ一ボン量の簡易測定手法の適用}

フライアッシュの未然カーボンは, フライアッシュコ ンクリート中において空気連行性を確保するための $\mathrm{AE}$ 剂を吸着し, 品質変動に与える影響が大きいことが言わ れている(1).この未燃カーボン量の測定について，JISで 規定された方法ではないものの, 従来の測定手法として メチレンブルー吸着量試験があり, 強熱減量とも高い相 関があることも知られている. このメチレンブル一吸着 量試験，強熱減量試験は，一般に手分析法で行われ，測 定時間も長く,メチレンブルー吸着量の測定においては 検量線作成などの前処理工程を除いても図ー1に示すよ うな一連の操作が必要となるの。 またた, フライアッシュの 品質管理手法として, 長瀧らはメチレンブルー吸着量以 外に密かさ比重を提案し4), フライアッシュコンクリート のAE剤使用量との間に高い相関関係を得ている.

筆者らは，更なる代替試験方法の提案として，絶乾状 態の試料を用いるのが前提であるが, 図一1のように測定 自体が短時間で，しかも全自動の機械測定で熟練した分 析手法を必要としない写真ー1のCHNコーダーを用いた 有機元素分析による炭素量測定 (簡易測定試験)を行い, 未燃カーボン量を測定した ${ }^{8)}$.この有機元素分析は, 化学 反応による反応生成物の化学量を電気量として求めるも のであり,ここではフライアッシュ中の炭素 (C) を燃焼 分解により, $\mathrm{CO}_{2}$ に変換し, 熱伝導度検出器でCの含有量 を検出し, 質量換算して含有率を\%で求めたものである. この測定結果を全炭素量とし, 従来の測定手法で得られ 


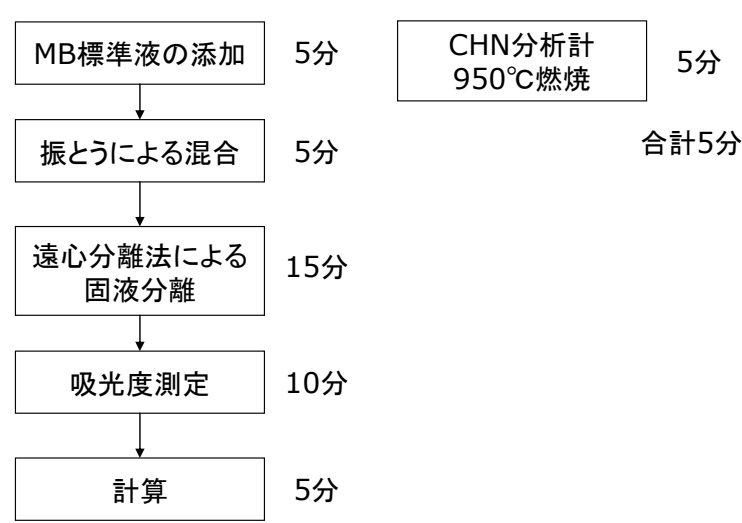

合計40分

図-1 未燃カーボン量の測定に要する時間

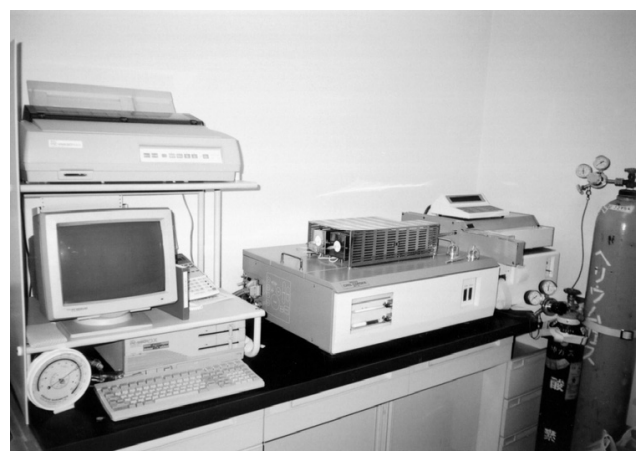

写真-1 CHNコーダー

た結果と比較を行い，フライアッシュの未燃カーボン量 の測定手法としての適用性を検討した.

（3）モルタル試験によるフライアッシュコンクリートの 性状評価手法の提案

a）簡易なモルタル試験によるフライアッシュの品質評 価

フライアッシュをレディーミクストコンクリート等へ 適用する場合，フライアッシュの品質を確認し，その品 質評価に対応してコンクリートの配合設計をする必要が ある.しかし，現状でフライアッシュを使用するには， 品質規格があるにも関わらず，フライアッシュに応じて コンクリートの配合試験を行い，所定のコンクリートの 品質を得るための単位水量, $\mathrm{AE}$ 剂量を求めている. 簡易 なモルタル試験でフライアッシュの品質評価ができれば, 生コン工場等におけるコンクリート製造時の品質管理が 容易となり，フライアッシュの混和材としての利便性の 向上が期待できる.ここで，モルタル試験によるフライ アッシュの品質評価には, JIS A 6201に流動性の改善効果 を判定する指標として，モルタルフロー值比があり，JIS II種の規格基準は95\%以上となっている.
表ー2 モルタル試験の配合ケース

\begin{tabular}{|c|c|c|c|c|c|c|}
\hline \multirow{2}{*}{$\begin{array}{l}\text { 検 討 } \\
\text { ケース }\end{array}$} & \multirow{2}{*}{$V_{w} / V_{p}$} & \multicolumn{4}{|c|}{ モルタルの配合 } & \multirow{2}{*}{ 備考 } \\
\hline & & W & $\mathrm{C}$ & FA & $\mathrm{s}$ & \\
\hline 基準 & 1.58 & 225 & 450 & - & 1350 & JIS A 5201配合 \\
\hline 内割 5 & 1.55 & \multirow{2}{*}{225} & 427.5 & 22.5 & \multirow{2}{*}{1350} & \\
\hline 内割 25 & 1.44 & & 337.5 & 112.5 & & JIS A 6201配合 \\
\hline 割 5 & 1.48 & \multirow{2}{*}{225} & \multirow{2}{*}{45} & 22.5 & \multirow{2}{*}{135} & \\
\hline 割 30 & 1.12 & & & 135 & & \\
\hline
\end{tabular}

本研究では，フライアッシュの置換率や置換方法を変 化させて性状を変えた表一2の組合せでモルタル試験を 行い, フライアッシュの品質の管理手法として各フロー 值比の適用を検討するとともに，フライアッシュコンク リートの単位水量, $\mathrm{AE}$ 剂量へ与える影響を検討した. モ ルタルの配合ケースは，フライアッシュをセメント質量 比に対し内割質量比で5\%，25\%（JIS R 6201），外割質量 比で $5 \%, 30 \%$ 混入したものとした. なお，表中の水粉体 容積比は式(1)により求めた. モルタルの練混ぜ，フロー 試験方法については，JIS R 5201に準拠した ${ }^{11)}$.

$$
\begin{aligned}
& \frac{V_{w}}{V_{p}}=\frac{W_{v}}{C_{v}+F A_{v}} \\
& \frac{V_{w}}{V_{p}}: \text { 水粉体容積比 }
\end{aligned}
$$

$$
\begin{aligned}
& W_{v}: \text { 単位水容積 } \\
& C_{v}: \text { 単位セメント容積 } \\
& F A_{v}: \text { 単位フライアッシュ容積 }
\end{aligned}
$$

\section{b） フライアッシュコンクリートの配合試験}

本研究のフライアッシュコンクリートは，フライアッ シュを細骨材充填混和材として細骨材の一部に使用した. この細骨材充填混和材として用いるフライアッシュの容 積置換率を既往の研究実績をもとに $10 \%$ とした ${ }^{9), 12)}$. フラ イアッシュコンクリートの配合条件は，水セメント比

（W/C）を $55 \%$ に設定し，目標スランプを $8 \pm 1 \mathrm{~cm}$ ，目標空 気量を $4.5 \pm 0.5 \%$ とした. フライアッシュコンクリートの 種類は, $\mathrm{AE}$ 剂を使用して空気量を調整したAEコンクリー トと，AE剂を使用しないNon-AEコンクリートの2種類と した．実験に用いた配合を表ー3に示すＡEコンクリー 卜の配合は, フライアッシュ混入率が $0 \%$ の基本配合 (PL 配合）および各フライアッシュを用いた配合（FA配合） の両者ともに所定のワーカビリティーが得られる範囲で 単位水量が最小となるように細骨材率を求め, 空気量は $\mathrm{AE}$ 剂の使用量で調整した。 その結果，フライアッシュの 種類に関わらず, AEコンクリートのFA配合では細骨材率 が全て $42 \%$ となった. Non-AEコンクリートの配合は, AE 
表－3 コンクリートの配合

\begin{tabular}{|c|c|c|c|c|c|c|c|c|c|c|}
\hline \multirow[b]{2}{*}{ 配合の種類 } & \multirow[b]{2}{*}{$\begin{array}{l}\text { フライアッ } \\
\text { シュの種類 }\end{array}$} & \multirow{2}{*}{$\begin{array}{c}\text { 水セメン } \\
\text { ト比 } \\
W / C \\
(\%)\end{array}$} & \multirow{2}{*}{$\begin{array}{c}\text { 細骨 } \\
\text { 材率 } \\
\text { s/a } \\
(\%)\end{array}$} & \multicolumn{7}{|c|}{ 単位量 $\left(\mathrm{kg} / \mathrm{m}^{3}\right)$} \\
\hline & & & & $\begin{array}{l}\text { 水 } \\
W\end{array}$ & $\begin{array}{c}\text { セメント } \\
\mathrm{C}\end{array}$ & $\begin{array}{c}\text { 細骨材 } \\
\text { S }\end{array}$ & $\begin{array}{c}\text { 混和材 } \\
\text { FA }\end{array}$ & $\begin{array}{c}\text { 粗骨材 } \\
\text { G }\end{array}$ & $\begin{array}{c}\mathrm{AE} \\
\text { 減水剂 }\end{array}$ & AE剂 \\
\hline \multirow{9}{*}{$\begin{array}{c}\mathrm{AE} \\
\text { コンクリート }\end{array}$} & - & \multirow{9}{*}{55} & 45.0 & 168 & 305 & 805 & 0 & 1047 & \multirow{9}{*}{$\begin{array}{c}C \times \\
0.25 \%\end{array}$} & 0.012 \\
\hline & $\mathrm{F} 1$ & & \multirow{8}{*}{42.0} & 165 & 300 & 681 & 67 & 1113 & & 0.091 \\
\hline & $\mathrm{F} 2$ & & & 167 & 304 & 678 & 69 & 1108 & & 0.085 \\
\hline & F3 & & & 168 & 305 & 676 & 66 & 1105 & & 0.119 \\
\hline & $\mathrm{F} 4$ & & & 167 & 304 & 678 & 68 & 1108 & & 0.137 \\
\hline & $\mathrm{F} 5(1)$ & & & 166 & 302 & 678 & 66 & 1109 & & 0.118 \\
\hline & $\mathrm{F5}(2)$ & & & 164 & 298 & 683 & 67 & 1116 & & 0.116 \\
\hline & $\mathrm{F} 5(3)$ & & & 167 & 304 & 678 & 67 & 1108 & & 0.075 \\
\hline & F5(4) & & & 168 & 305 & 676 & 64 & 1105 & & 0.120 \\
\hline \multirow{9}{*}{$\begin{array}{c}\text { Non-AE } \\
\text { コンクリート }\end{array}$} & - & \multirow{9}{*}{55} & 45.0 & 168 & 305 & 805 & 0 & 1047 & \multirow{9}{*}{$\begin{array}{c}C \times \\
0.25 \%\end{array}$} & - \\
\hline & $\mathrm{F} 1$ & & \multirow{8}{*}{42.0} & 168 & 305 & 676 & 66 & 1105 & & - \\
\hline & F2 & & & 168 & 305 & 676 & 68 & 1105 & & - \\
\hline & F3 & & & 168 & 305 & 676 & 66 & 1105 & & - \\
\hline & $\mathrm{F} 4$ & & & 168 & 305 & 676 & 67 & 1105 & & - \\
\hline & $\mathrm{F} 5(1)$ & & & 168 & 305 & 676 & 66 & 1105 & & - \\
\hline & $\mathrm{F5}(2)$ & & & 168 & 305 & 676 & 66 & 1105 & & - \\
\hline & $\mathrm{F5}(3)$ & & & 168 & 305 & 676 & 67 & 1105 & & - \\
\hline & F5(4) & & & 168 & 305 & 676 & 64 & 1105 & & - \\
\hline
\end{tabular}
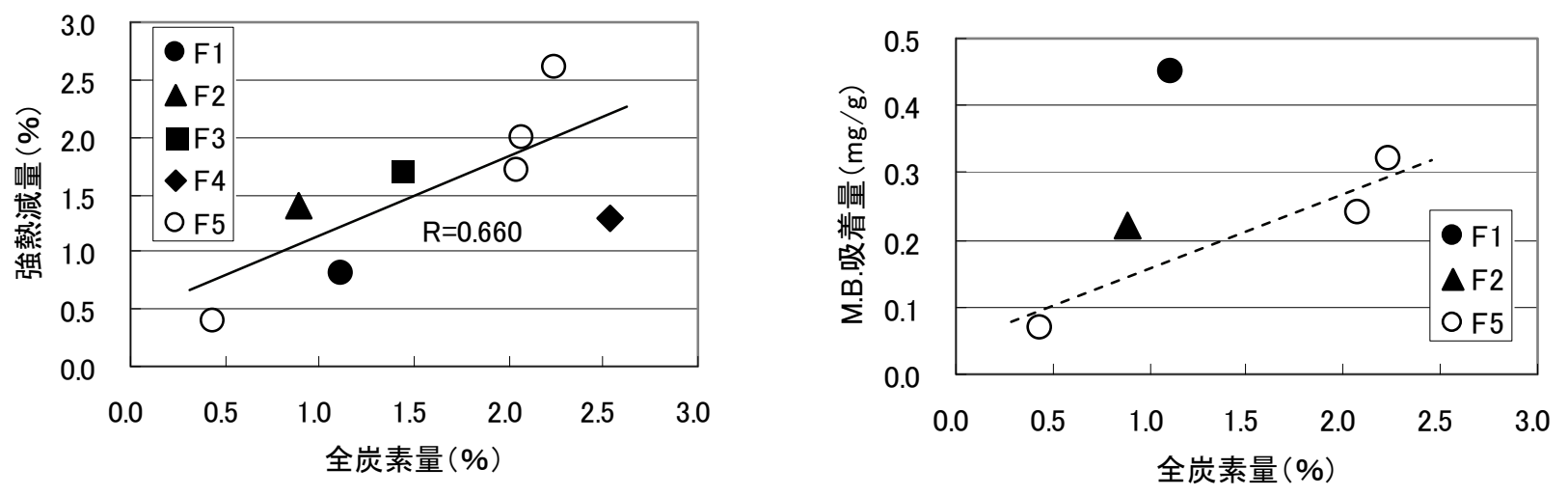

図－2 簡易測定手法 (全炭素量) と従来測定手法の関係

コンクリートの結果を基に，単位水量を $168 \mathrm{~kg} / \mathrm{m}^{3}$ に固定

し, 細骨材率はPL配合で45\%, FA配合で42\%一定とした。

コンクリートの練混ぜは，容量55リットルの強制二軸 ミキサ内に，粗骨材，フライアッシュ，セメント細骨材 の順に投入して，30秒空練りした後，混和剤を予め加え た練混ぜ水を投入して90秒間練り混ぜた。一回の練混ぜ 量は40リットルとした. フレッシュコンクリートについ ては, スランプ試験, 空気量試験を, それぞれJIS A 1101, JISA 1128に準拠して行った.

\section{3. フライアッシュの品質とその特性評価}

\section{（1）未燃カ一ボン量の簡易測定手法の適用性評価}

図一2に未燃カーボン量の簡易測定結果 (全炭素量) と 従来手法の測定結果 (強熱減量, メチレンブルー吸着量)
の関係を示す，全炭素量と強熱減量の関係は，ばらつき もあるものの, 全炭素量の増加とともに強熱減量も増加 傾向を示しており，相関が認められる.メチレンブルー 吸着量との関係は，強熱減量と同様に全炭素量の増加と ともに増加傾向が認められるが，ばらつきが大きい.こ こで，従来手法の測定結果の比較として，図一3に強熱減 量とメチレンブル一吸着量の関係を示す。図より，従来 手法においてもばらつきが確認できる. 西條らば), 手分 析法によるメチレンブルー吸着量試験で未燃カーボン量 の少ない試料を用いた場合，測定誤差の影響でばらつき が大きいことを明らかにしている，本研究においても， 使用したフライアッシュが全てJIS II種で，しかも強熱減 量が3.0\%以下の未然カーボン量の少ないと推測できる 試料であることから，メチレンブル一吸着量のばらつき が大きくなった可能性が高い.また，図一4に全炭素量と 密かさ比重の関係を示す. 全炭素量は従来測定手法と同 


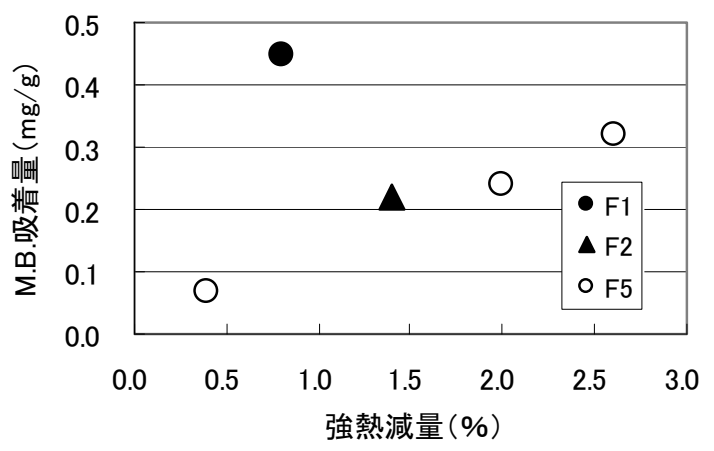

図－3 強熱減量とメチレンブルー吸着量の関係
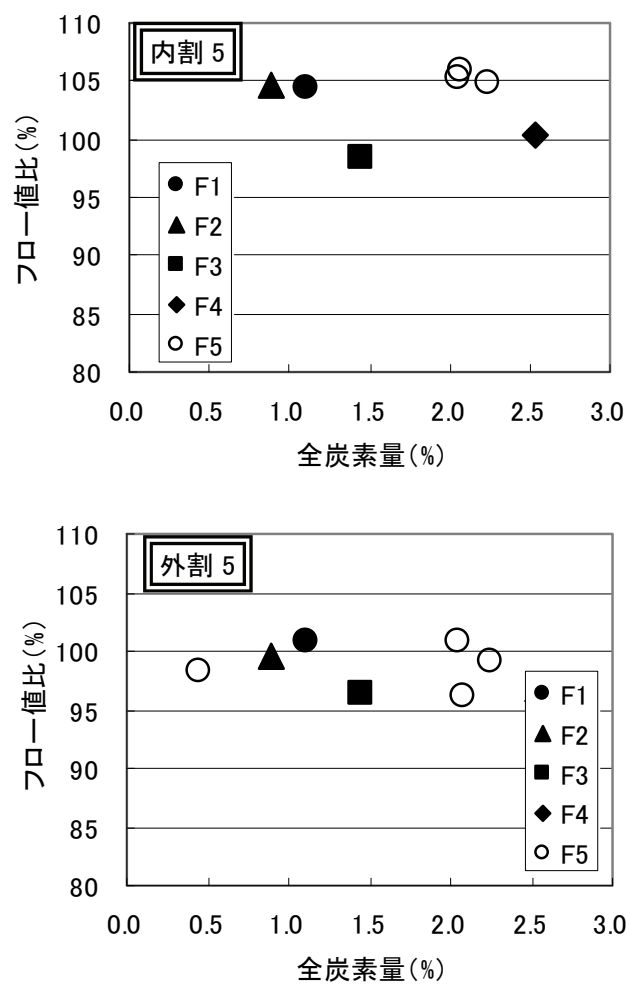

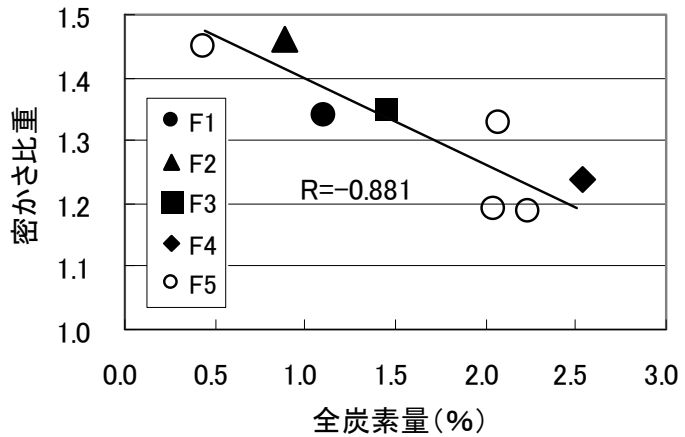

図-4 全炭素量と密かさ比重の関係
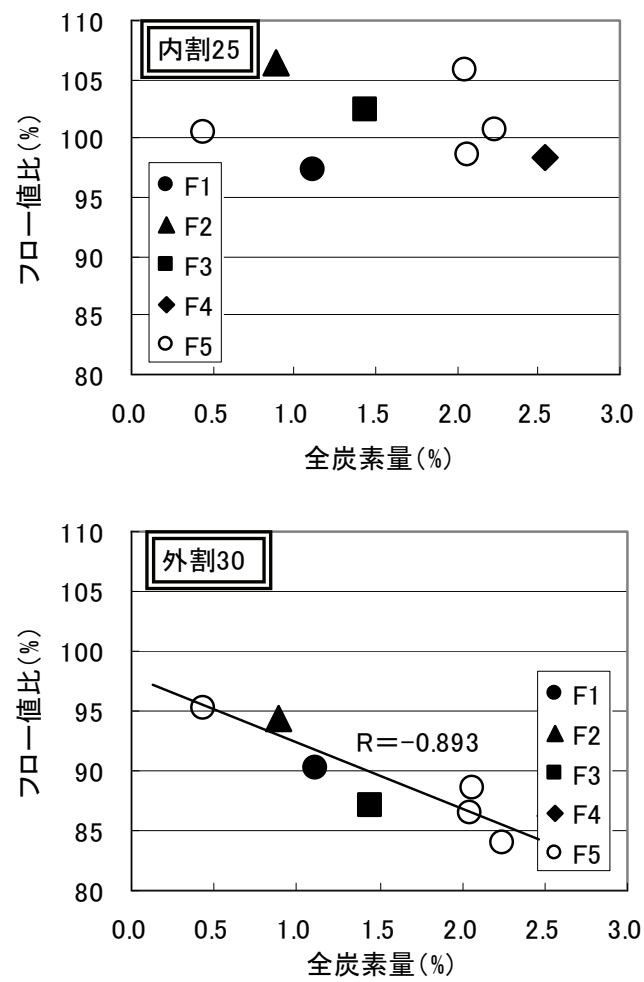

図－5 全炭素量と簡易モルタル試験の各フロー值比の関係

様に密かさ比重とも高い相関が認められる.

全炭素量は，従来手法のような間接的な測定でなく直 接的な測定が可能であり, 強熱減量, メチレンブル一吸 着量および密かさ比重よりも高い精度でフライアッシュ 中の未燃カーボン量を示していることが確認できる.

\section{（2）フライアッシュのモルタル試験による品質評価}

図一5にモルタル試験で得られたフロー值比と全炭素 量の関係を配合別に示す.フライアッシュの置換率，置 換方法の違いにより，フロー值比と全炭素量との関係が 異なっていることが分かる. 内割25配合はフライアッ シュの品質に関するJIS A 6201で規定されている配合で あり, F1〜F5のいずれのフライアッシュもJIS II種のフ ロー值比の規格 (95\%以上) を満足している. 外割5配合
は，フライアッシュの混入量が少ないが，水粉体容積比 が1.48で内割25配合（1.44）と近く，フロー值比も95 105\%の範囲で内割25とほぼ同程度となっている.この内 割25配合, 外割5配合とも類似した特徵を有しているが, フロー值比と全炭素量との間に相関関係は認められない. 内割 5 配合は, 配合ケースの中で水粉体容積比が 1.55 と最 も大きく, 内割25配合に比べて粘性が小さく, フロー值 比も $100 \sim 110 \%$ 程度と他に比べて大きいが，全炭素量と の間に相関は認められない. 一方，外割30配合は水粉体 比が1.12と小さく, 内割25配合に比べて粘性が大きく, フロー值比が85～95\%程度となっている. このフロー值 比と全炭素量との間には高い相関が認められ，フロー值 比が小さくなるほど全炭素量が増加する傾向が得られた. ここで，全炭素量は未燃カーボン量を直接的に示す指 


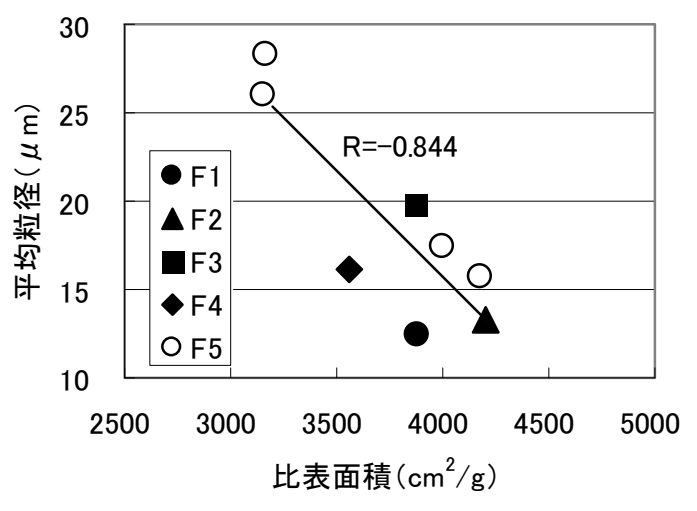

図－6 比表面積と平均粒径の関係

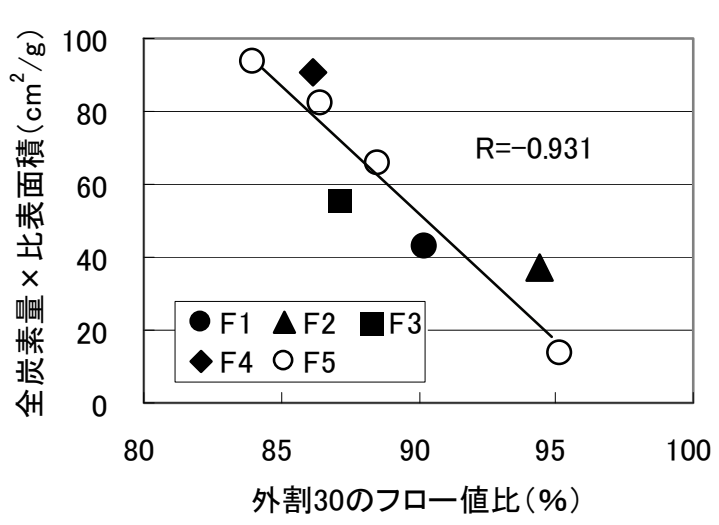

図－7 モルタル試験の外割30のフロー值比と 全炭素量 $\times$ 比表面積の関係

標であるが，モルタルのフロー試験はフライアッシュ の形状の違いなどの間接的な影響も多分に受けている と考えられる. 全炭素量と外割30のモルタルフロー值 比が同様のフライアッシュの特性を評価しているので あれば，フライアッシュの形状の影響を全炭素量との 関係で明確にすることで精度向上が図れると推察でき る. また, 既往の研究においても, フライアッシュの 形状等がフライアッシュの諸性質に与える影響が大き いことが報告されている(13), 14),15).このため，フライ アッシュの形状の影響についてフライアッシュの平均 粒径を基に検討を加えた。図一6に平均粒径とJS規格 基準の指標の一つである比表面積との関係を示す. 本 研究で用いたフライアッシュの平均粒径は比表面積と 高い相関性が得られた. このことから, 全炭素量と比 表面積の積を求め, 外割30配合のフロー值比との関係 を求めた. その結果, 図一7に示すように相関係数が 0.93 となり, 全炭素量単独との相関係数 (0.89) に比べ て高く, 未然炭素量と比表面積の積は, モルタルフロー 值比に対して良好な相関を呈した。モルタル試験は, 特殊な機械を必要とせず, 熟練を要する必要もなく, 生コン工場や現場でのコンクリート製造におけるフラ

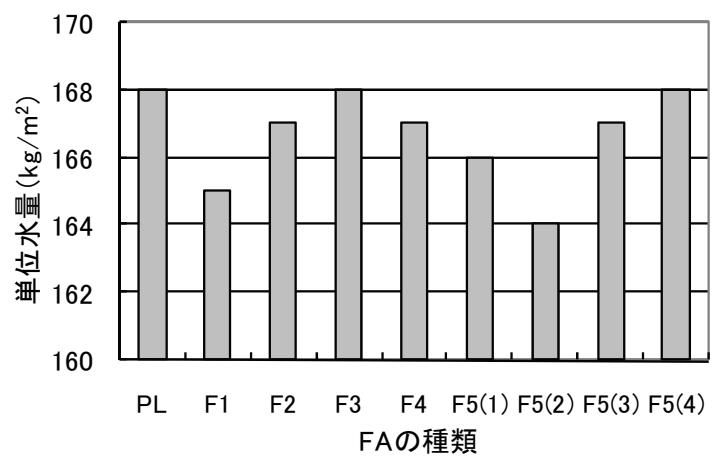

図一8 $\mathrm{AE}$ コンクリートのFAの種類と単位水量の 関係

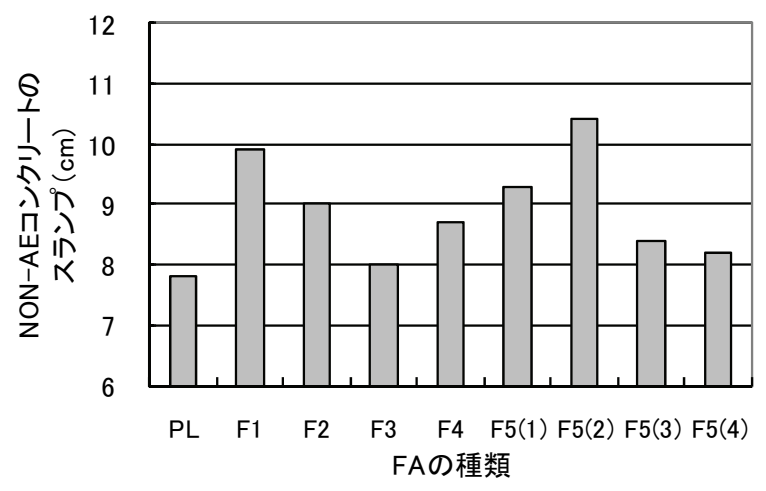

図－9Ｎon-AEコンクリートのFAの種類とスラン プの関係

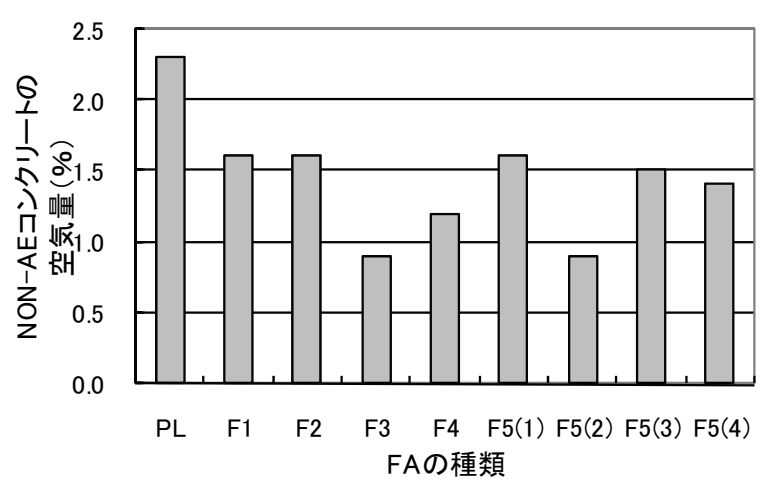

図ー10 Non-AEコンクリートのFAの種類と空気量 の関係

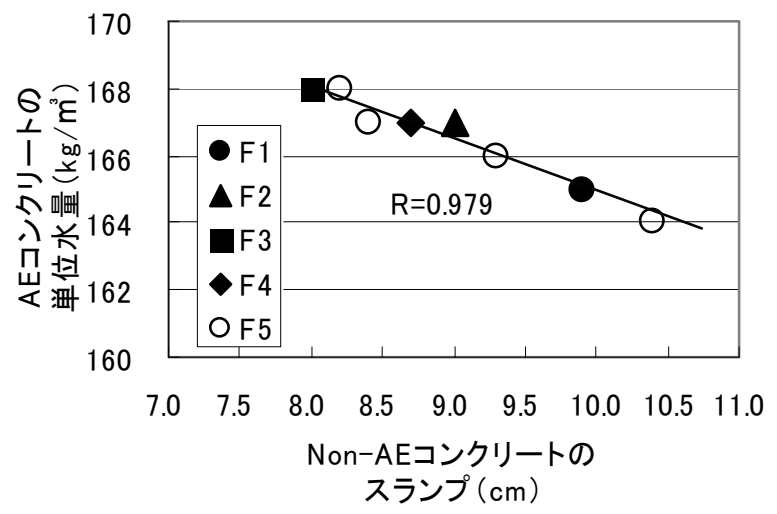

図－11 Non-AEコンクリートのスランプとAEコンク リートの単位水量の関係 

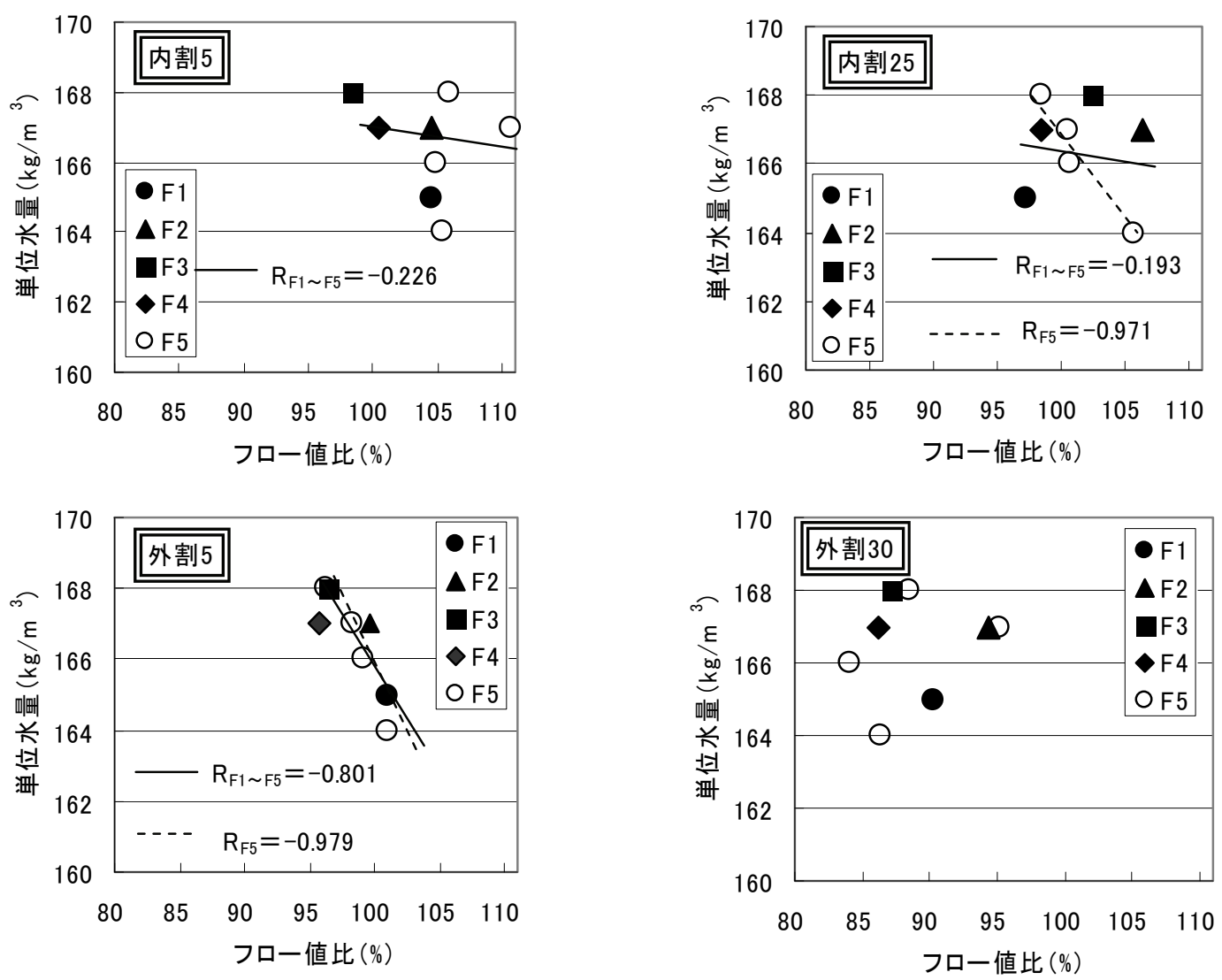

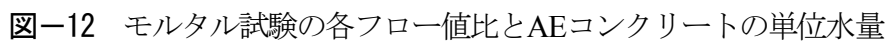

イアッシュの品質管理に優れた評価手法と考えられる.

4. フライアッシュの品質がフレッシュコンク リートの性状に与える影響

（1）フライアッシュの品質がスランプおよび単位水量に 与える影響

\section{a）スランプと単位水量}

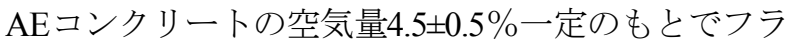
イアッシュの種類別に，スランプ $8 \pm 1 \mathrm{~cm}$ を得るのに必要

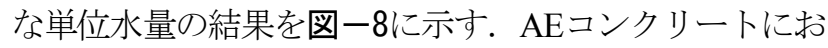
けるFA配合の単位水量は, PL配合 $\left(168 \mathrm{~kg} / \mathrm{m}^{3}\right)$ に比べて 同等以下となっている. 使用したフライアッシュは全て JIS II種で，比較的品質が安定しているにも関わらず，単 位水量は164〜 $168 \mathrm{~kg} / \mathrm{m}^{3}$ の範囲で変化している.

Non-AEコンクリートの単位水量一定で空気量無調整 におけるスランプの測定結果を図ー9に, 空気量の測定結 果を図ー10に示す. Non-AEコンクリートのFA配合のス ランプは, フライアッシュの種類により差があるものの, PL配合に比べて同等以上となっている.これは，図一10 に示すように, Non-AEコンクリートのFA配合がPL配合 に比べて空気量が少なく，一定でないにも関わらず，フ

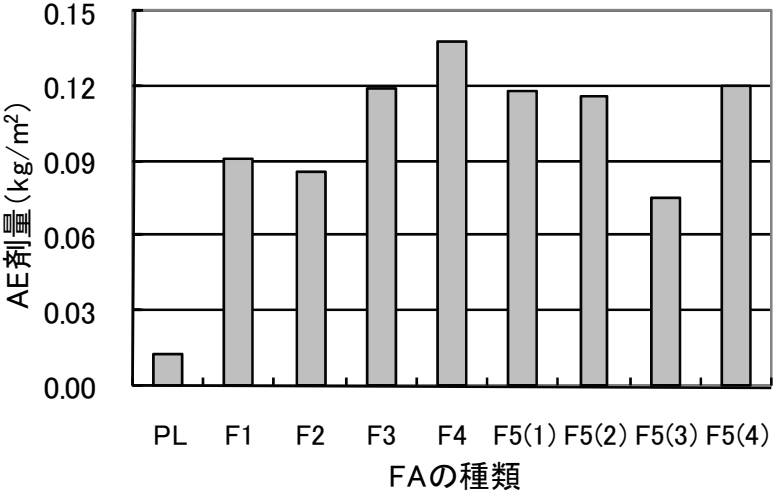

図ー13 AEコンクリートのFAの種類と空気量の関係

ライアッシュが球状の微粒子であるためにワーカビリ ティーの改善に寄与したものと考えられる. 図ー11に Non-AEコンクリートのスランプとAEコンクリートのス ランプ $8 \pm 1 \mathrm{~cm}$ を得るのに必要な単位水量との関係を示す. Non-AEコンクリートのスランプは，AEコンクリートの 単位水量との間に高い相関関係が得られた。これは, $\mathrm{AE}$ コンクリートの単位水量が空気量の影響を受けることな く, フライアッシュの品質そのものの影響で差異を生じ たものと判断できる. このように，フライアッシュコン クリートの単位水量が，空気量の影響も受けず，そのフ ライアッシュの品質のみによって定量的に決定されるも 

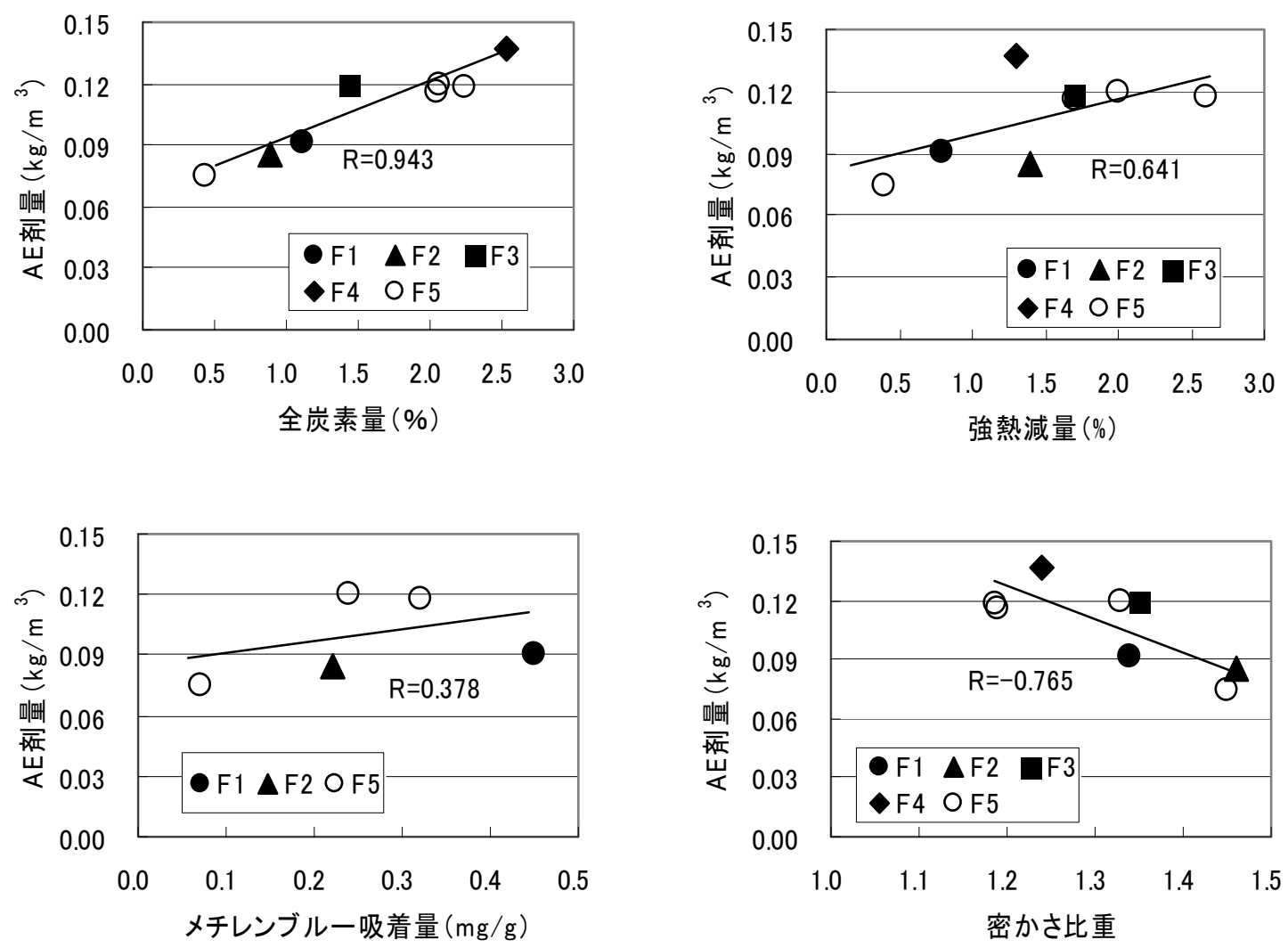

図-14 各種測定手法による未燃カーボンの測定結果とAE剂量の関係

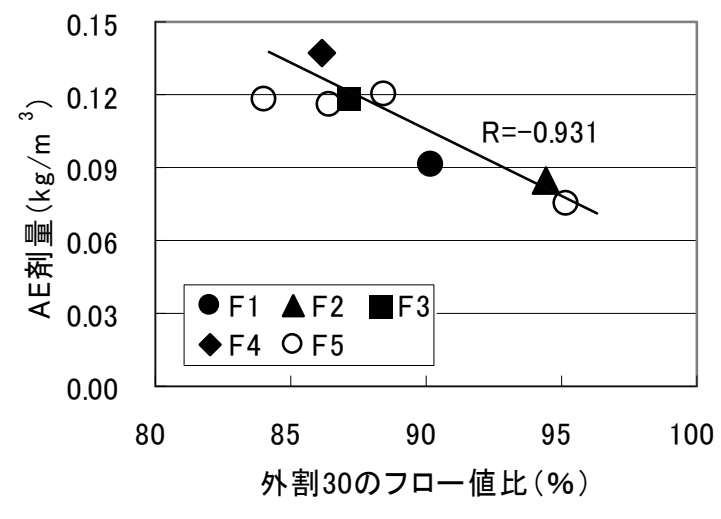

図ー15 モルタル試験の外割30配合のフロー值 比とAE剂量の関係

のであれば, フライアッシュコンクリートの配合設計に おいて試験練り等をすることなく，フライアッシュの品 質変動によるコンクリートのスランプ変動に迅速に対応 できる手法の開発が期待できる.

\section{b）モルタル試験と単位水量の関係}

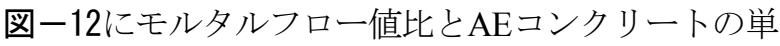
位水量の関係を示す. 配合ケースごとのフロー值比と単 位水量の関係は, 内割5配合では全体的に右下がりの傾向 を示すものの，相関は低い.内割25配合と外割5配合では 右下がりの傾向が見られ，内割25配合はF5で，外割5配
合はF5およびその他の全てのフライアッシュで，フロー 值比が大きくなるに従って単位水量が直線的に減少する 傾向となった. 外割5配合は, フライアッシュの種類に関 係なく, フロー值比とAEコンクリートの単位水量との間 に高い相関が認められ，フライアッシュコンクリートの 単位水量に与える影響を鋭敏に評価できる可能性が確認 できた，今後，更なるデータの蓄積が必要であるが，モ ルタル試験で単位水量を推定できたことは，フライアッ シュの品質によるスランプ変動に迅速に対応できる手法 として期待できる. なお，外割30配合での相関は認めら れなかった.

\section{（2）フライアッシュの品質が空気量に与える影響}

\section{a) AE剂の使用量と未燃カーボン量}

$\mathrm{AE}$ コンクリートの空気量 $4.5 \pm 0.5 \%$ を得るのに使用し たAE剤量をフライアッシュの種類別に図ー13に示す. FA 配合のAE剤量はフライアッシュの種類が全てJIS品質規 格のI種であるにも関わらず違いがあり，使用するAE剂 量が最も多いF4がF5(3)に比べて約2倍にもなっている. これは, フライアッシュ中の未然カーボンのAE剤吸着作 用がフライアッシュの種類により変動するためと考えら れる. 図ー14に各種測定手法による未燃カーボンの測定 結果とAE剂量の関係を示す.いずれもAE剂量との間に相 
関関係があり, 相関が高い順に, 全炭素量, 密かさ比重, 強熱減量, メチレンブルー吸着量となった. この結果, 本研究で提案した簡易測定方法 (全炭素量) は，フライ アッシュがJIS II種の同一規格基準でも, 未然カーボン量 の少ない範囲まで精度良く未燃カーボン量を測定できる ものと判断され，精度をはじめ作業性等を総合的に評価 した場合，従来方法と同等以上の未燃カーボン量の優れ た測定手法であることを改めて確認できる.

\section{b） $\mathrm{AE}$ 剂の使用量とモルタル試験}

図ー15にモルタルの外割30配合のフロー值比と単位 $\mathrm{AE}$ 剂量の関係を示す.外割30配合のフロー值比とAE剂量 との間には高い相関が認められ，簡易なモルタル試験に よってAE剂量が推定できている，このことは，既往の物 性值ではばらつきが大きくコンクリート試験での判断が 必要であったフライアッシュも, 簡易なモルタル試験で AE剂量を高い精度で推定できる可能性を得た.

ここで，フライアッシュコンクリートはそのフライ アッシュの置換率や置換方法よって異なるが，通常のコ ンクリートに比べて粘性が増加する ${ }^{9)}$. 本研究は, このフ ライアッシュの粘性に着目し，モルタルフロー值比によ る検討を行った。この結果，外割30配合がAE剂量と相関 が成り立ち，4. (1) b)に記述したように外割5配合が単位 水量と相関が成り立った. フライアッシュコンクリート は, 所定のフレッシュ性状確保のための単位水量とAE剂 量の調整においてフライアッシュの品質変動の影響を受 けるが，これを本研究の範囲内ではモルタルフロー值比 によって定量的に評価できたものと考えられる. ただし， 詳細については明らかでなく，今後さらに検討する必要 がある。

\section{5. 結論}

本研究は, 日本国内の4電力会社5石炭火力発電所より 採取した計8種類のフライアッシュを用いて，フライアッ シュコンクリートの簡易品質評価手法について検討した. 本研究の範囲で得られた知見を以下に示す.

（1）未燃カーボン量の簡易測定手法として提案した有機 元素分析は, 強熱減量, メチレンブルー吸着量および 密かさ比重と相関が認められた。

(2) フライアッシュをセメント質量比に対し外割質量比 で 30\%混入したモルタルフロー值比は，全炭素量と の間で相関が認められ，未燃カーボン量の測定手法 として適用性が認められた。

(3) フライアッシュの JIS 規格基準が同一（II 種）にも関 わらず，フライアッシュを細骨材補充材料として用 いたフライアッシュコンクリートは, 単位水量が 164 〜 $168 \mathrm{~kg} / \mathrm{m}^{3}$ の範囲で変化し，空気連行性を確保する
ための $\mathrm{AE}$ 剂量が約 2 倍もの範囲内で変化した.

(4) フライアッシュコンクリートの所定のコンクリート の品質を確保するための単位水量とフライアッシュ をセメント質量比に対し外割質量比で 5\%混入した モルタルフロー值比との間には高い相関が認められ た.

(5) フライアッシュコンクリートの所定のコンクリート の品質を確保するための $\mathrm{AE}$ 剂量とフライアッシュ をセメント質量比に対し外割質量比で $30 \%$ 混入した モルタルフロー值比との間には高い相関が認められ た.

以上の結果より，フライアッシュの有効利用において 特にフライアッシュコンクリートに及ぼす影響が大きい とされる未然カーボン量の品質管理に関して，筆者らが 適用した有機元素分析は直接的な評価手法として，簡易 なモルタル試験は間接的な評価手法として適用の可能性 を得た. また，フライアッシュコンクリートの配合設計 におけるフレッシュ性状の品質を確保するための単位水 量およびAE剤量について，コンクリートの試験練り等を することなく，簡単なモルタル試験で定量的に評価でき る可能性を得た. 今後, 生コン工場などにおいて, フラ イアッシュの品質変動に即応して，スランプ，空気量の 調整が可能な手法の開発に繋がるものと期待できる.

謝辞 : 本研究は，土木学会フライアッシュ有効利用研究 小委員会よりフライアッシュを提供して頂きました。ま た，本研究を実施するにあたり，福岡大学工学部社会デ ザイン工学科18，19年度施工システム研究室卒論生の協 力を得ました.ここに記して謝意を表します.

\section{参考文献}

1）(財)石炭エネルギーセンター：石炭灰全国実態調査報 告書（平成 17 年度実績），2005。

2) 宮原茂禎, 大沢栄也, 坂井悦朗, 大門正機: フライアッ シュ一セメント系の水和反応, セメント・コンクリー 卜論文集，No.54，pp.50-55，2000.

3) 松藤泰典, 磯辺敏幸, 小山智幸, 重富光人 : 石炭灰を コンクリートに大量使用するための安定化処理に関 する研究, コンクリート工学年次論文集, Vol.22, No.2, pp.115-120， 2000.

4) 長瀧重義, 大賀宏行, 増田和機, 谷直樹 : フライアッ シュコンクリートの品質管理手法に関する研究, コン クリート工学年次論文報告集, Vol.9, No.1, pp.223-228, 1987.

5) 田野崎隆雄, 野崎賢二, 白坂優, 成島良輔 : コンクリー 卜混和材用石炭灰の品質評価および管理について, コ ンクリート工学年次論文集, Vol.7, No.1, pp.337-342, 1985.

6) 西条英敏, 豊永弘典, 重本直也, 柳原哲, 谷沢祐一 : フライアッシュのメチレンブルー吸着自動測定装置, 火力原子力発電, Vol.49, No.9, pp.1189-1195, 1998.

7) 江藤弘之, 赤塚剛, 山本晃 : フライアッシュの品質変 
動がコンクリートに及ぼす影響について，コンクリー 卜工学年次論文集, Vol.24, No.1, pp.111-116, 2002.

8) 楠貞則, 添田政司, 大和竹史 : フライアッシュの簡易 品質評価手法, 第 62 回年次学術講演会講演概要集, 5-235, pp.469-470, 2007.

9) 土木学会四国支部 : フライアッシュを細骨材補充混和 材として用いたコンクリートの施工指針(案), 2003.

10) 奥野亨, 浅野研一, 大浦鉄男: フライアッシュコンク リートの空気連行性について, セメント技術年報, No.38, pp.150-153, 1984.

11) 土木学会 : 2005 年制定 コンクリート標準示方書規準 編, 2005.

12) 古賀善雄, 船本憲治, 藤本浩 : フライアッシュを外割
り使用したコンクリートの諸特性, コンクリート工学 年次論文集，Vol.28，No.1，pp.1643-1648， 2006.

13）長瀧重義, 大賀宏行, 三宅且仁 : 分級したフライアッ シュのコンクリート混和材としての適用性, 東工大土 木研究報告, No.35, 1985 .

14) Ohga, H.: A Fundamental Study on Application of Fly Ash as an Admixture for Concrete, The Tokyo Institute of Technology dissertation, 1991.

15) 大賀宏行, 國分勝郎, 坂井悦郎, 大門正機 : フライアッ シュの潜在的品質とモルタルの諸物性, コンクリート 工学年次論文報告集, Vol.8, No.1, pp.339-344, 1996.

(2008. 2.7 受付)

\section{A STUDY ON THE SIMPLE QUALITY ASSESSMENT OF CONCRETE WITH FLY ASH}

\section{Sadanori KUSUNOKI, Masashi SOEDA and Takeshi YAMATO}

Although the quality of fly ash is classified by JIS, the effective use of fly ash as a mineral admixture of concrete has been hindered because there is a concern that the quality of concrete with fly ash is largely fluctuated depending on the quality of fly ash. In addition, although there have been many studies on concrete with fly ash as a part of fine aggregate, the method of quality control of the concrete with fly ash has not yet been sufficiently established. In this study, an easy method to evaluate the quality of fly ash was developed, and then the influence of fly ash quality on the fresh property of concrete with fly ash was experimentally investigated. As a result, a simplified method of measuring the quantity of un-burnt carbon, the most important factor in fly ash, was proposed. The quality evaluating method of concrete with fly ash by a simplified mortar test was also proposed. 